\title{
KOMUNIKASI DAKWAH PEMUDA HIJRAH
}

\author{
Nur Ratih Devi $\mathbf{A}^{\mathbf{1}}$, Meria Octavianti ${ }^{2}$ \\ ${ }^{1}$ Universitas Pasundan, ${ }^{2}$ Universitas Padjdjaran
}

\begin{abstract}
ABSTRAK
Pemuda Hijrah yang lebih dikenal dengan "shift" merupakan sebuah komunitas dakwah yang berhasil mengajak remaja Kota Bandung mengisi kebutuhan rohani dengan datang ke mesjid. Bukan hanya melakukan kajian, tetapi Pemuda Hijrah kerap melakukan kegiatan lain yang berkaitan dengan anak muda dengan nuansa Islami.Penelitian ini berupaya untuk mengetahui dan menganalisis komunikasi dakwah yang dilakukan oleh Pemuda Hijrah, yang meliputi sumber komunikasi, pesan yang disampaikan, media yang digunakan, dan perubahan sikap yang terjadi di kalangan anak muda Kota Bandung.Metode penelitian kualitatif dipilih untuk penelitian ini dengan pendekatan studi kasus deskriptif. Teknik pengumpulan data primer dilakukan dengan wawancaradanobservasilangsung, sedangkan data sekunder diperoleh melaluti studi literatur yang dilakukan pada berbagai sumber bacaan yang relevan dengan topik penelitian. Hasil penelitian menunjukkan bahwa dengan komunikasi dakwah yang dilakukan PemudaHijrah di kalangan anak muda kota Bandung dapat mengubah pemikiran anak muda akan adanya suatu kajian dan dapat pula merubah sikap mereka untuk antusias datang kekajian Pemuda Hijrah. Komunikasi dakwah yang digunakan menggunakan media yang tepat dan mengikuti gaya anak muda akan tetapi tetap dalam aturan Islam.
\end{abstract}

Kata-kata Kunci: Komunikasi Dakwah, Pemuda Hijrah, Kota Bandung

\section{MOSLEM MISSIONARY COMMUNICATION OF PEMUDA HIJRAH}

\begin{abstract}
Pemuda Hijrah as well as "Shift" is a Moslem missionary community who made Bandung City teenagers fulfilled their spiritual needs by came to the Mosque. Not only studied the religion, but also done activities related to teenagers with Islamic nuance. This research attempted to know and analyze the Moslem missionary communication done by Pemuda Hijrah, those include the source of Moslem missionary communication, the delivered message, the used of media and the attitude transformation of the Bandung City teenagers. Qualitative method was choose with descriptive case study approach. The data was collected by depth interview and observation, while the secondary data taken by literature study with several read related to the research topic. The result showed that the Moslem missionary communication done by Pemuda Hijrah can change their mind and their point of view about the religious study and also more enthusiastic to come. The message and the media chosen by used teenagers' way of life but still in Moslem corridor.
\end{abstract}

Keywords: Missionary Communication, Pemuda Hijrah, Bandung

Korespondensi: Dr. Nur Ratih Devi Affandi, S.S., M.Si. Universitas Pasundan. Jl. Lengkong Besar No.68, Cikawao, Lengkong, Kota Bandung, Jawa Barat 40261 Email: ratihaffandi83@ gmail.com 


\section{PENDAHULUAN}

Menyeru manusia ke arah kebaikan dalam agama Islam merupakan kewajiban bagi setiap umat untuk menjalankannya. Mengajak sesama ke arah jalan kebaikan sejalan dengan kaidah-kaidah agama Islam yang akhinya membawa umat pada kebahagiaan yang sebenarnya. Menyeru dan mengajak manusia untuk menjalankan perintah Yang Maha Kuasa secara semantic disebut dakwah.

Kegiatan dakwah memantapkan fokus pada pengembangan dan penyampaian dakwah atau lebih dikenal dengan komunikasi dakwah. Komunikasi dakwah merupakan salah satu hal yang penting untuk kegiatan dakwah. Keberhasilan kegiatan dakwah tergantung dari bentuk penyampaian pesan yang dilakukan. Komunikasi dakwah dalam hal ini dalam bentuk kajian mingguan atau harian juga diskusi yang dilakukan guna membuat pesan menjadi lebih efektif atau sampai tepat pada penerimanya.

Komunikasi dakwah tentu saja komunikasi yang berisi pesan-pesan kebaikan dalam agama Islam. Pesan yang sengaja disampaikan oleh pemberi pesan kepada penerima pesan baik dalam bentuk orasi, diskusi maupun dalam bentuk lainnya sesuai dengan perkembangan zaman. Misalnya dengan pengguanaan media sosial berupa akunakun yang memuat konten-konten agama, simbolsimbol agama yang sesuai dengan target atau penerima pesan. Komunikasi dakwah tentu saja merupakan interaksi komunikasi positif yang mencakup aktivitas jasmani-rohani dan metalintelektual baik dengan sentuhan massa maupun sentuhan personal dalam segala sisi kehidupan. Kemajuan teknologi yang tidak bisa dihindari dewasa ini tentu ssaja memaksa para penggiat dakwah untuk juga terjun menggunakannya. Dakwah yang dengan berdiri di depan menggunakan mimbar, pasifnya respon dari audience, asap rokok yang mengepul pekat nampaknya kini bukan menjadi tren di kalangan masyarakat, khususnya generasi muda dewasa ini. Cara penyampaian pesan yang baik tentu saja harus dengan menggunakan cara yang baik pula. Media yang tepat kan membuat pesan yang disampaikan tepat sasaran. Media semestinya diperhatikan karena dapat mempengaruhi masyarakat (Wahyudin,Ronauli, Elita, Mirawati, 2016:125). Media juga merupakan alaty persuasi yang ampuh (Barezki \& Hafiar, 2016:1).

Dewasa ini masyarakat banyak menaruh perhatian pada media sosial. Hal ini tentu saja merupakan sebuah fenomena yang tidak terelakan dan menjadi tantangan tersedniri dalam penyampaian pesan dakwah. Pesan dakwah yang dikemas menarik sehingga dapat meraih perhatian masyarakat luas, diharapkan bisa menjadi penyampaian pesan yang efektif di masa sekarang. Citra akan dakwah merupakan sesuatu yang sifatnya kolot dan membosankan bisa berubah menjadi berjiwa muda dan menyenangkan. Hal ini tentunya akan sangat berpengaruh pada penerimaan pesan dakwah yang diberikan.

Pemuda Hijrah atau Shift adalah gerakan pemuda yang ingin membawa generasi muda ke jalan yang diridhai oleh Allah. Pemuda hijrah merupakan sebuah komunitas keagamaan yang 
mewadahi dan memfasilitasi para pemuda yang ingin berhijrah dan ingin lebih mendekatkan diri kepada Allah SWT. Kegiatan tersebut mampu membawa perubahan pada diri pada pemuda untuk memantapkan langkah. Pemuda Hijrah sendiri berdiri sejak tahun 2015 yang terdiri dari sekumpulan komunitas-komunitas anak muda di Kota Bandung seperti skateboard, musik indie, dan anggota geng motor yang telah mengikrarkan diri untuk berhijrah mendalami agama Islam. Keberadaan para komunitas tersebut tentunya membuat anak muda lainnya tertarik dengan gerakan Shift.

Shift berhasil membangun persepsi anak muda terkait dengan kajian Islam yang cenderung membosankan. Sejalan dengan yang telah diungkap sebelumnya bahwa kajian kegamaan identik dengan hal yang berbau kolot dalam hal ini peserta kajian yang rata-rata orang tua dan kontenkonten yang disuguhkan membosankan. Namun komunitas Pemuda Hijrah Shift dapat mengubah identifikasi tersebut menjadi sesuatu yang dekat dengan generasi muda dan menyenangkan.

Gerakan-gerakan yang dilakukan oleh komunitas Pemuda Hijrah berupa serangkaian kajian rutin yang dilaksanakan di setiap hari Rabu dan Sabtu dengan tema dan pemateri yang berbeda di setiap kajiannya. Sedangkan pada hari Sabtu kajian dilaksanakan di Masjid Al-Lathiif yang berada di Jalan Saninten No. 2 Bandung. Adapula kajian yang dilakukan setiap hari Rabu dilaksanakan di Masjid Trans Studio Mall. Tetapi terkadang Pemuda Hijrah melakukan gerakan GoShift yang berupa roadshow di setiap masjid yang berbeda di Kota Bandung serta Shift Dadakan yakni kajian yang diadakan secara dadakan, tentu saja waktu dan tempat yang diinfokan mendadak pada hari yang sama. Sedangkan Kajian Rabu disampaikan oleh Ustad Tengku Hanan Attaki pukul 18.00-21.00. Adapula ladies day atau yang dikenal dengan Kajian Sabtu pada pukul 09.0011.00 disampaikan oleh Teh Haneen. Setiap hari Sabtu pukul 18.00-20.30 disebut Kajian Malam Mingguan oleh ustad yang berbeda-beda. Dilanjutkan dengan dengan qiyyamul lail yaitu melaksanakan baca Qur'an dan solat tahajjud bersama. Hal ini dapat membawa anak muda di Kota Bandung untuk mengikuti setiap kegiatan yang diadakan oleh Pemuda Hijrah. Hal ini dapat tercermin dari pengikut Instagram @shiftmedia.id yang sampai tanggal 10 Februari 2019 sudah memiliki pengikut sebanyak 1,9 juta followers.

Berdasarkan pada paparan di atas, maka penelitian ini berupaya untuk mengungkap bagaimana bentuk komunikasi dakwah yang dilakukan oleh Pemuda Hijrah kepada anak-anak muda di Kota Bandung. Dimana fokus penelitian terbagi kepada tiga pertanyaan yaitu (1) bagaimana sumber dan pesan komunikasi dakwah Pemuda Hijrah (Shift)?, (2) bagaimana media komunikasi dakwah Pemuda Hijrah (Shift)?, (3) bagaimana sikap dari penerima pesan komunikasi dakwah Pemuda Hijrah (Shift)?

\section{METODE PENELITIAN}

Penelitian ini menggunakan metode kualitatitif dengan pendekatan studi kasus. Penelitian ini berusaha memberikan uraian dan 
penjelasan komprehensif mengenai bentuk komunikasi dakwah yang dilakukan oleh komunitas Pemuda Hijrah kepada anak-anak muda di Kota Bandung. Hal tersebut sesuai dengan apa yang disampaikan oleh Mulyana (2002: 201) bahwa studi kasus merupakan uraian dan penjelasan komprehensif mengenai berbagai aspek seorang individu, suatu kelompok, suatu organisasi (komunitas), suatu program, atau suatu situasi sosial. Dengan mempelajari semaksimal mungkin seorang individu, suatu kelompok, atau suatu kejadian, peneliti ingin memberikan pandangan yang lengkap dan mendalam mengenai subjek yang diteliti.

Penelitian ini bersifat holistik dan multisources, sehingga peneliti mengumpulkan data dari berbagai sumber yang terkait dengan topik yang dikaji dalam penelitian ini. Data penelitian diperoleh dengan menggunakan beberapa metode pengumpulan data seperti observasi, wawancara, dan studi literatur.

\section{Bagan 1}

Komponen Analisis Data Kualitatif Model Interaktif (Interactive Model)

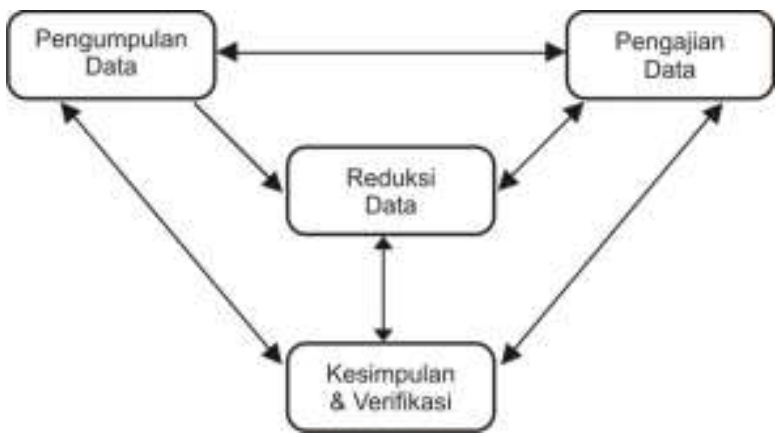

Sumber: Matthew B. Miles \& Michael A. Huberman (1992) dalam Agus Salim (2001: 22)

Analisis data dalam penelitian ini dilakukan dengan mengggunakan interactive model, yang terdiri dari tiga tahap yaitu (1) proses pemilihan, yaitu pemusatan perhatian pada penyederhanaan, abstraksi, dan transformasi data kasar yang di peroleh di lapangan atau yang biasa dikenal dengan reduksi data (data reduction), (2) penyajian data (data display), yaitu mendeskripsikan kumpulan informasi yang telah tersusun, untuk selanjutnya dilakukan (3) penarikan kesimpulan dan verifikasi (conclusion drawing and verification).

Di dalam penelitian kualitatif terdapat subjek dan objek penelitian. Menurut Moleong (2010) subjek penelitian ialah informan yang memiliki latar penelitian yang dimanfaatkan untuk memberikan informasi mengenai penelitian tersebut. Adapun subjek dalam penelitian ini adalah beberapa informan kunci yang terdiri dari (1) tim manajemenPemuda Hijrah, (2) partisipan Pemuda Hijrah, dan (3) jamaah yang mengikuti berbagai kegiatan dakwah yang diadakan oleh Pemuda Hijrah. Adapun jumlah informan dalam penelitian ini adalah 3 informan ahli dan 7 informan pendukung. Objek penelitian dalam penelitian ini adalah proses komunikasi dakwah Pemuda Hijrah pada anak muda Kota Bandung.

\section{PEMBAHASAN}

\section{Sumber dan Pesan Komunikasi Dakwah Pemuda Hijrah (Shift)}

Sumber dalam proses komunikasi merupakan hal yang penting karena peran sumber dapat mempengaruhi penerima sehingga yang dihasilkan ialah sikap atau tindakan yang berubah. Berdasarkan observasi yang dilakukan oleh peneliti, posisi da'i memiliki peran yang penting 
dalam mempengaruhi sikap pemuda di Kota Bandung untuk mengikuti berbagai kajian yang diadakan oleh Pemuda Hijrah. PosisiHanan Ataki sebagai da'i dari Pemuda Hijrah sangat mempengaruhi anak muda untuk turut serta dalam berbagai aktivitas yang diadakan oleh Pemuda Hijrah. Salah satuinforman yang merupakan jamaah, menyatakan tertarik untuk mengikutiberbagai aktivitas yang diadakan Pemuda Hijrah ini karena keberadaan ustadz Hanan yang dianggap memiliki peran yang lebih banyak dan juga paling menarik perhatian anak muda. Hanan Ataki sebagai seorang founder dianalogikan sebagai programmer dalam mengelola berbagai konten dalam berbagai media sosial yang digunakan oleh Pemuda Hijrah. Penggunaan bahasa yang digunakan oleh Hanan Ataki yang tepat membuat orang khususnya anak muda berantusias mengikuti Pemuda Hijrah (shift) dibandingkan dengan ustadz lain seperti ustadz Imam, ustadz Abe, dan ustadz lainnya.

Namun imbauan dari ustadz Hanan bahwasannya ilmu bisa didapatkan tidak harus terpaku pada satu ustadz membuat sebagian jamaah yang hanya terpaku dengan satu ustadz pun menjadi sadar dan akhirnya mengikuti kajian ustadz lain walaupun hal tersebut tidak membuat jamaah berkurang dan tetap banyak seperti biasanya. Hal tersebut didukung dengan pendapat informan yang menjelaskan bahwa ia menjadi mencari ilmu atau kajian yang lain karena imbauan yang dilakukan oleh ustadz Hanan tersebut dan juga fakta yang ditemukan dilapangan kajian yang dilakukan oleh gerakan selain Pemuda Hijrah menjadi banyak.

Sumber di sini juga dijadikan patokan oleh tim untuk mencari ustadz yang serupa tetapi masih menunjukan keorisinalitas dari da'i tersebut temuan tersebut diperkuat oleh pendapat yang dilontarkan oleh informan ahli yang menjelaskan bahwa ustadz yang mengisi di Pemuda Hijrah harus mempunyai keluwesan dan dapat menyampaikan pesan sesuai dengan bahasa anak muda.Berdasarkan observasi yang dilakukan, banyaknya ustadz muda bermunculan. Gaya yang disampaikan oleh ustadz muda tersebut biasanya tidak jauh dari gaya ustadz Hanan saat berdakwah, hal tersebut positif karena banyak anak muda yang menjadi mencari kajian yang diisi oleh ustadzustadz muda.

Sumber atau da'i disini juga ikut mempengaruhi kajian yang dilakukan oleh gerakan dakwah lainnya. Berdasarkan observasi yang dilakukan setelah mengikuti beberapa kajian memang beberapa ada yang mengikuti gaya kajian yang dilakukan oleh Pemuda Hijrah, contohnya Pemuda Hidayah yang dimana salah satu materi kajiannya lebih kepada menyangkut kepada kehidupan anak muda hal tersebut diperkuat dengan pendapat dari informan ahli ustadz Imam yang mengatakan setelah beliau mengisi di Pemuda Hijrah banyak tawaran salah satunya di Pemuda Hidayah yang mengikuti pola yang sama dengan pemuda hijrah (Shift), kemudian tidak hanya sampai disitu ustadz Imam juga menuturkan banyak gerakan-gerakan dakwah lainnya yang ingin diisi oleh ustadz dari Pemuda Hijrah hal 
tersebut, dengan temuan tersebut pun dapat dinilai bahwa sumber atau da'i dari Pemuda Hijrah memang sangat berpengaruh tidak hanya dipihak jamaah tetapi pihak eksternal, berdasarkan temuan yang dilakukan memang ustadz yang mengisi memiliki usia yang masih muda.

Peran pemberi pesan dalam suatu komunikasi dakwah tidak hanya dilakukan oleh da'i akan tetapi juga peran humas juga melakukan tugasnya sebagai komunikator karena memiliki tugas dan fungsi menyebarkan informasi walaupun informasi yang dilakukan berbeda akan tetapi secara umum fungsinya masih tetap sama.

Selain itu, penampilan da'i yang ditampilkan juga mengikuti penampilan anak muda sebagian dai yang mengisi di Pemuda Hijrah tidak memakai pakaian yang biasanya seperti gamis dan lain lain, akan tetapi lebih kepada baju koko, dan sebagian besar menampilkan pakaian kemeja, sweater Pemuda Hijrah (Shift) meskipun tidak ada ketentuan mengenai pakaian da'i dari tim Pemuda Hijrah (Shift) akan tetapi selama observasi yang peneliti lakukan dan ikuti seperti itu pakaian dari da'i yang mengisi di dalamnya.

Berdasarkan hasil wawancara dengan informan pendukungjuga dapat disimpulkan bahwa hal yang membuat sebagian besar informan tertarik dalam kajian Pemuda Hijrah (Shift) ini adalah karena sumber / dai yang memiliki kredibilitas dalam penyampaian pesannya. Kredibilitas adalah tingkat kepercayaan seseorang pada seorang pembicara, jika kredibilitas pemberi pesan buruk berarti pembicaraannya pun buruk begitu pun sebaliknya, hal tersebut yang menjadi alasan jamaah anak muda untuk mengikuti kajian Pemuda Hijrah (Shift) ini diperkuat karena cerita pengalaman diceritakan oleh da'i ustadz Hanan yang hampir disetiap materi kajiannya selalu diselingi dengan pengalamannya sehingga membuat jamaah tertarik karena pengalaman yang ternyata ustadznya pun pernah mengalami hal yang tidak beda jauh dengan anak muda. Anggota / volunteer dari Pemuda Hijrah (Shift) ini tertarik menjadi volunteer berawal dari sumber yang dapat menyampaikan pesan secara komunikatif dan dapat dimengerti karena penggunaan bahasa yang mengikuti trend zaman sekarang selaras dengan yang dikemukakan oleh informan ahli dalam menentukan sumber / da'i di Pemuda Hijrah (Shift) memang disesuaikan dengan jamaahnya yaitu anak muda.

Juga dalam penyampaian pesan dapat melalui bahasa yang sesuai dengan bahasa anak muda (semi formal) hal tersebut sesuai dengan ayat yang ada didalam Al-Qur'an surat Ibrohim ayat 4 yang berbunyi "Kami tidak mengutus seorang rasulpun, melainkan dengan bahasa kaumnya, supaya ia dapat memberi penjelasan dengan terang kepada mereka. Maka Allah menyesatkan siapa yang Dia kehendaki, dan memberi petunjuk kepada siapa yang Dia kehendaki. Dan Dialah Tuhan Yang Maha Kuasa lagi Maha Bijaksana" dari surat tersebut menurut Kang Inong sebagai informan ahli, saat Rasul menyampaikan dakwah itu sesuai dengan bahasa kaumnya.

Pesan dakwah merupakan piranti lunak yang disampaikan oleh pendakwah melalui ceramah atau tablig, pesan komunikasi dakwah 
yang berupa yang berupa informasi yang dapat memotivasi audiens (jamaah), diambil dari ajaran agama disertai dengan penjabarannya. Pesan-pesan dakwah hendaknya mampu membangkitkan dorongan atau motivasi.

Hal tersebut sehubungan dengan pesan yang disampaikan oleh Pemuda Hijrah (Shift), dalam penyampaiannya pesan yang disampaikan dapat memotivasi jamaah khususnya anak muda untuk melakukan hal yang baik selaras dengan teori dan hasil observasi yang dilihat dari beberapa tema kajiannya.Hal ini sejalan dengan yang diungkapkan informan bahwa pesan yang ada didalam kajian ada beberapa macam yakni mengasah logika, motivasi, dan memberi ilmu.

Selain itu juga pesan yang disampaikan tidak hanya secara langsung melalui kajian akan tetapi juga melalui komunikasi audio visual (video) yaitu salah satunya one minute booste, rmerupakan cara lain agar anak muda tertarik dengan pesan yang disampaikan oleh Pemuda Hijrah (Shift). One minute booster adalah suatu potongan 1 menit video di media sosial instagram dari ustadz Hanan sebagai pengisi suaranya. Potongan video itupun sesuai dengan penyampaian pesan yang ingin disampaikan oleh Pemuda Hijrah dengan tujuan untuk menjadi pendorong keimanan di kalangan anak muda.Hal tersebut didukung oleh pendapat dari informan, bahwa video tersebut sangat efektif untuk meningkatkan keimanan.

Hal tersebut sesuai dengan peluang keberhasilan dakwah apabila dibarengi dengan keahlian mengemas pesan dakwah menjadi lebih menarik dan dapat dipahami komunikannya yaitu lebih berorientasi kepada anak muda disampaikan dengan cara berpikir dan cara merasa, ini pun berhubungan dengan penyampaian pesan yang disampaikan oleh sumber/dai komunikator dakwah yang tidak terkenal dapat memperkuat pemahaman psikologisnya sehingga memperkuat efektivitas pesannya, sebagaimana yang diketahui bahwa Ustadz Hanan, ataupun ustadz yang mengisi di Pemuda Hijrah tidak terlalu dikenal oleh masyarakat sebelumnya akan tetapi dengan memahami psikologis atau apa yang dirasakan oleh anak muda melalui pesan-pesan dakwah yang ringan dan penyampaian yang santai juga tidak terlalu kaku, itupun dapat membuat mereka lebih dikenal dikalangan anak muda penyampaian pesan pun menjadi efektif dalam mengubah sikap anak muda khususnya di Kota Bandung.

\section{Media Komunikasi Dakwah Pemuda Hijrah (Shift)}

Komunikasi dakwah dapat berlangsung dengan media atau tanpa media. Namun, seiring dengan perkembangan zaman, penggunaan media sebagai saluran penyampaian ajaran islam. Media yang digunakan oleh Pemuda Hijrah (Shift) ialah meliputi media sosial yaitu Instagram, Youtube, Whatsapp, Line, dan aplikasi yang bisa didownload di Play Store.

Berdasarkan hasil observasi yang dilakukan bahwa Pemuda Hijrah (Shift) memang turut aktif dalam media sosial Instagram dengan username (@pemudahijrah) telah diikuti oleh 1,9 juta pengikut, dibandingkan dengan komunitas pemuda dakwah lainnya pemuda hijrah termasuk kepada 
berhasil mengajak anak muda mengikuti akun dakwah.

Hal tersebut yang menjadi pekerjaan bagi Pemuda Hijrah untuk terus memperbarui kemasan diinstagram agar lebih menarik khususnya perhatian anak muda. Seperti saat membuat poster info kajian, poster tersebut disebarkan melalui media sosial Instagram baik diunggah di Instagram maupun di fitur Instagram yaitu instastory.Berdasarkan hasil pengamatan yang dilakukan oleh peneliti, poster yang disebarkan cukup mengikuti trend anak muda, contohnya dalam salah satu unggahan poster yang disebarkan yang berjudul " $H O P E$ "dimana desain dari poster tersebut mencirikan anak muda, karena dibalik desain ini dengan kata hope terdapat beberapa filosofi bahwa dari kata hope tersebut disusun oleh kata $\mathrm{H}$ gambar buku KUA yang mencerminkan pernikahan, kata $\mathrm{O}$ disusun oleh gambar $\mathrm{Ka}$ 'bah yang mencerminkan naik haji, $\mathrm{P}$ disusun oleh gambar pantai, dan E disusun oleh gambar kopi. Hal tersebut dapat didefinisikan melalui caption dalam foto tersebut bahwa fitrah manusia memang banyak keinginan khususnya anak muda yang menginginkan menikah, ingin membuka usaha, ingin memberangkatkan haji orang tua, dan ingin bisa travelling kemanapun. Hal tersebut adalah halhal yang ingin dilakukan oleh anak muda, dan itu poster itupun dibuat seperti itu agar menarik perhatian anak muda.

Kemudian untuk penggunaan video pun turut dimanfaatkan dalam menyebarkan info kajian salah satu contohnya ialah video berjudul Empathy disitu terlihat bahwa saat diperjalanan pulang ada sekelompok orang yang memakai motor tua, dan seseorang yang sedang menggunkan skateboard untuk menuju ke perjalanan, kemudian salah satu dari sekelompok orang tersebut balik lagi untuk memberikan bantuan kepada yang menggunakan skateboard agar bisa meneruskan bersama dengan cara memberikan ajakan untuk bisa berbarengan ke perjalanan tersebut.

Video menjadi menarik perhatian anak muda ketika video yang mereka buat itu sendiri dengan berlatarkan pantai. Kemudian menggunakan skateboard sebagai mainan dalam kalangan anak muda, dalam captionnya pun menggunakan bahasa yang tidak baku.

Sedangkan dalam penggunaan media sosial Youtube-nya sendiri Pemuda Hijrah (Shift) sangat cepat dalam mengupload hasil kajiannya, selain cepat dalam unggahannya Pemuda Hijrah (Shift) pun menyiarkan kajiannya secara langsung yaitu dengan streaming di youtube Pemuda Hijrah.

Penggunaan Whatsapp dimanfaatkan untuk pengikut yang ingin mengetahui informasi tambahan Pemuda Hijrah (Shift), peneliti pun memanfaatkan Whatsappmemanfaatkan media tersebut untuk membuka komunikasi dengan pihak Shift untuk melakukan penelitian ini.Sedangkan untuk line pun dimanfaatkan untuk menyebarkan kajian yang sebenarnya telah disebarkan melalui media sosial akan tetapi disebarkan kembali lewat aplikasi line, agar bisa tersebar luas.Untuk aplikasinya yang terdapat di Play Store belum bisa digunakan karena adanya konfirmasi dari informan ahli Kang Tinton bahwa memang dari aplikasi tersebut belum di rilis secara resmi. Media sosial 
yang digunakan selanjutnya adalah twitter dimana hal tersebut digunakan sebagai media untuk menyebarkan informasi mengenai kegiatan atau hasil unggahan dari Pemuda Hijrah (Shift)

Analisis berdasarkan hasil wawancara dengan para informan menunjukkan bahwa alasan informan pendukung mengikuti sosial media yang dimiliki oleh Pemuda Hijrah (Shift) dikarenakan ingin mengetahui informasi seputar kajian yang dilaksanakan dan sebagian besar dari informan pendukung mengetahui kajian untuk pertama kali dari media sosialselain itu juga informan pendukung mengakui keefektifan pesan dakwah yang disampaikan melalui media sosial dikarenakan konten/ isi yang menarik yang dapat pula meningkatkan keimanan informan pendukung selain itu juga tidak hanya info kajian tapi media sosial pun digunakan untuk menyebarkan informasi donasi kepada orang-orang yang membutuhkan, kemudian ini menjadi selaras dengan pendapat informan ahli yang menyatakan bahwa media sosial yang digunakan diisi dengan konten yang sesuai dengan kehidupan anak mudakemudian diviralkan oleh tokoh-tokoh anak muda yang memang sudah hijrah akan tetapi tidak meninggalkan kebiasaan positif dulunya

Hal ini tentu saja menjadi hal yang tidak lagi sulit diterima oleh anak muda karena riset menunjukkan berdasarkan data di Departemen Komunikasi dan Informasi (Depkominfo) (2013, hlm. 1) dapat diketahui bahwa "Indonesia saat ini mencapai 63 juta orang.Dari angka tersebut, 95 persennya menggunakan internet untuk mengakses jejaring sosial".Memasuki era globalisasi, remaja merupakan kalangan yang sering menggunakan media internet khusunya media sosial sebagai sarana untuk mencari informasi, hiburan maupun berkomunikasi dengan teman di situs jejaring sosial.

Berdasarkan data yang diperoleh Depkominfo (2012, hlm. 1) dapat diketahui bahwa "semakin banyak pengguna internet merupakan anak muda.Mulai dari usia 15-20 tahun dan 10-14 tahun meningkat signifikan”. Media sebagai sarana penunjang bagi manusia untuk memenuhi kebutuhan akan informasi maupun hiburan. Ini menunjukkan bukan tidak mungkin dakwah Pemuda Hijrah tidak disebarkan melalui jejaring sosial karena itu kemasan media sosial dari Pemuda Hijrah dikemas dengan sedemikian rupa agar menarik perhatian anak muda, dimulai dengan pembuatan video yang menarik yang dimana video yang Pemuda Hijrah ambil memang direkam langsung oleh para anggota/volunteer Pemuda Hijrah, kemudian tema poster yang membuat rasa penasaran dikalangan anak muda kota Bandung.

Sikap dari Penerima Anak Muda Kota Bandung

\section{Sikap dari Penerima Pesan Komunikasi Dakwah Pemuda Hijrah (Shift)}

Sikap yang terbentuk dalam anak muda adalah sikap yang masih memerlukan pengertian emosional, terkadang tindakan yang dilakukan oleh anak muda masih dalam tahap sesuai dengan emosional yang mereka rasakan, hal inilah yang rupanya menjadi sasaran atau target dari gerakan Shift Pemuda Hijrah untuk lebih bisa mengajak anak muda khususnya di Kota Bandung untuk lebih 
banyak melakukan kegiatan yang positif dengan cara memotivasi melalui kegiatan dakwah yang sesuai dengan apa yang anak muda alami.

Berdasarkan unsur-unsur yang telah dijelaskan sebelumnya dimulai dari sumber/ dai terkait, pesan yang disampaikan oleh dai tersebut dan media penggunaan dakwah tersebut dapat dihasilkan bahwasannya memang adanya respon dari penerima khususnya dari anak muda itu sendiri, beberapa mengatakan bahwa tertarik dari Pemuda Hijrah memang dari ustadz Hanan yang memiliki suara lembut dalam membacakan ayat $\mathrm{Al}$ Quran hal tersebut disampaikan oleh informan pendukung pertama yaitu Rosa Farida, adapun yang tertarik karena pesan yang disampaikan sesuai dengan apa yang terjadi dalam kehidupannya seperti yang disebutkan oleh Putri bahwasannya dirinya sedang mengalami perubahan sikap untuk menjadi lebih baik, sebagian besar dari informan pendukung mendapatkan manfaat dari media sosial sebagai sarana untuk meningkatkan keimanannya kembali saat tidak adanya kajian secara langsung.

Berdasarkan hasil wawancara yang dilakukan peneliti dengan informan dapat disimpulkan bahwa komunikasi dakwah yang dilakukan oleh Pemuda Hijrah (Shift) mempengaruhi perubahan sikap informan pendukung dalam kehidupan sehari-harinya, mereka menjadi pribadi yang lebih baik dalam bertingkah laku dikesehariannya, salah satunya ada yang memang dari awal tidak mengenal islam setelah mengikuti kegiatan Pemuda Hijrah (Shift) ia pun menjadi semangat mencari ilmu mengenai islam.

Adanya perubahan sikap dari anak muda merupakan selaras dengan teori yang dikeluarkan oleh Hovland bahwa komunikasi memiliki efek kuat pada sikap, Hovland menjelaskan secara alami seseorang akan tertarik pada pembelajaran dan motivasi.

Hal tersebut membuktikan bahwa komunikasi dakwah yang dilakukan Pemuda Hijrah efektif untuk kalangan anak muda, karena Pemuda Hijrah (Shift) melakukan pendekatan secara psikologis. Menurut Tubbs dan Moss, efektivitas komunikasi paling tidak ditandai dengan adanya pengertian, yaitu adanya penerimaan dari semua kalangan anak muda baik yang sudah baik penampilannya maupun yang tidak, kesenangan, yaitu difasilitasi atau disajikan dengan mainan anak muda seperti skateboard, sepeda, dan lain-lain, yang mengakibatkan kepada pengaruh pada sikap anak muda yang semakin baik sikap secara kepribadian maupun kepada lingkungannya contohnya kepada orang tua, kepada lawan jenis yang bisa menyikapi dengan bijak sesuai dengan syariat islam. Pada penggunaan bahasa yang digunakan oleh Pemuda Hijrah dalam penyampaian dakwahnya kepada anak muda dapat merepresentasikan level ditingkat yang sama, seolah-olah da'i dalam penyampaian dakwah mengerti akan kondisi yang dialami oleh anak muda dan memberikan solusinya terkait permasalahan tersebut yang juga dapat mendekatkan diri kepada Allah, tidak hanya itu kegiatan bermain yang dilakukan membuat anak 
muda semakin bisa dihargai. Hal tersebut dilakukan untuk menumbuhkan kesenangan para jemaah. Sebab, dengan komunikasi iniakan timbul hubungan yang komunikatif dan menyenangkan, dengan demikian kesenangan ini akan menjadi jembatan persuasi dan salah satu tujuan dari komunikasi persuasif adalah untuk adanya perubahan sikap.

\section{PENUTUP}

Citra dakwah yang kerap kali dikaitkan atau identik dengan generasi tua bisa berubah menjadi identik dengan kaum muda. Perubahan berada di tangan generasi muda, maka sudah seharusnya mereka menjadi generasi yang lebih baik. Metode penyampaian pesan yang tepat tentunya bisa membuat pesan sampai pada sasarannya. Dakwah yang diperuntukan untuk kaum muda tentu saja harus menggunakan cara-cara yang digandrungi oleh mereka. Penelitian ini menjawab akan cara menyampaikan pesan pada kaum muda gune mebuat perubahan sikap ke arah positif. Pesan yang disampaikan dengan mengunakan sosial media baik berupa gambar, paragraf maupun video pendek dengan konten dan kemasan yang menarik dipercaya bisa membuat anak muda tergerak untuk datang dan mendengarkan kajian yang dilakukan di masjid. Peran komunikator tentu saja tidak bisa dielakkan dalam komunikasi dakwah, dalam hal ini seorang ustadz yang bisa membawa para remaja yang sangat membutuhkan pendekan emosional bisa tergerak untuk mendengarkan, menyimak dan pada akhirnya berusaha mengamalkannya.
Penelitian yang telah dilakukan menunjukkan bahwa komunikasi dakwah yang bisa meraih hati pemuda masih sangat dibutuhkan di era digital sekarang ini di mana informasi bisa didapatkan dengan sangat mudah, maka dari itu hendaknya ada peran pemerintah dan peran akademisi untuk bisa menyebarluaskan virus kebaikan ini.

\section{DAFTAR PUSTAKA}

Azjen, I. 2002. Percieved Behaviral Control, Self Eficacy, locus of control, and the theory of planned behavioural. Journal of Applied Social Psichology.

Arikunto, S. 2007. Prosedur Penelitian: Suatu pendekatan Praktek. BT Bina Aksara. Jakarta.

Barezki, F.E., Hafiar, H., 2016, Proses Persuasi Ruang Film Bandung Kepada Komunitas Film Bandung dalam Program klinik Film, diakses dari Jurnal ProTVF Vol 1 No 1, doi http://dx.doi.org/10.24198/ptvf.v1i1.13328

Denzin, Norman \& Ivonna S. Lincoln. 1994. Handbook of Qualitative Research. London: Sage Publication.

Ember, Carol R. \& Melvin Ember. 1990. Anthropology. 6th ed. New Jersey : Prentice Hall.

Fisher, B. Aubrey. 1978. Perspectives on Human Communication. New York : MacMillan Publishing Co.

Griffin, EM. 2003. A First Look at Communication Theory. 5th ed. Boston : McGraw-Hill.

Hovland, Carl.L. 2007. Definisi Komunikasi. PT Raja Grafindo. Jakarta

Keesing, Roger M. 1999. Antropologi Budaya: Suatu Perspektif Kontemporer. Terjemahan. Edisi ke-2. Jakarta : Erlangga. 
Littlejohn, Stephen W. 1999. Theories of Human Communication. 6th ed. Belmont : Wadsworth Publishing.

Littlejohn, Stephen W \& Karen A. Foss. 2008. Theories of Human Communication, 9th ed. Belmont :Thomson Wadsworth.

Moleong, Lexy J. 2010. Metode Penelitian Kualitatif. Bandung: Remaja Rosdakarya

Mulyana, Deddy. 2002. Metodologi Penelitian Kualitatif. Bandung : PT Remaja Rosdakarya.

Salim, Agus. 2001. Teori dan Paradigma Penelitian Sosial. Yogyakarta: Tiara Wacana

Suriasumantri, Yuyun S. 2000. Filsafat: Sebuah Pengantar Populer. Jakarta : Pustaka Sinar Harapan.

Wahyudin, U., Ronauli, M., Elita, F.M., Mirawati, I., 2016, HUBUNGAN ANTARA PESAN KAMPANYE 9 AKSI RAMAH LINGKUNGAN DI AKUN TWITTER EARTH HOUR BANDUNG DENGAN SIKAP FOLLOWERS AKTIF TERHADAP GAYA HIDUP RAMAH LINGKUNGAN, diakses dari Jurnal Manajemen Komunikasi Vol 1 No 1,

doi http://dx.doi.org/10.24198/jmk.v1i1.11017 